Old Dominion University

ODU Digital Commons

Bioelectrics Publications

Frank Reidy Research Center for Bioelectrics

$2-2018$

\title{
Inactivation of Myeloma Cancer Cells by Helium and Argon Plasma Jets: The Effect Comparison and the Key Reactive Species
}

Zeyu Chen

Qingjie Cui

Chen Chen

Dehui Xu

Dingxin Liu

See next page for additional authors

Follow this and additional works at: https://digitalcommons.odu.edu/bioelectrics_pubs

Part of the Biophysics Commons, Cancer Biology Commons, Cell Biology Commons, Organic Chemicals Commons, Physics Commons, and the Therapeutics Commons

\section{Repository Citation}

Chen, Zeyu; Cui, Qingjie; Chen, Chen; Xu, Dehui; Liu, Dingxin; Chen, H. L.; and Kong, Michael G., "Inactivation of Myeloma Cancer Cells by Helium and Argon Plasma Jets: The Effect Comparison and the Key Reactive Species" (2018). Bioelectrics Publications. 145.

https://digitalcommons.odu.edu/bioelectrics_pubs/145

\section{Original Publication Citation}

Zeyu, C., Qingjie, C., Chen, C., Dehui, X., Dingxin, L., Chen, H. L., \& Kong, M. G. (2018). Inactivation of myeloma cancer cells by helium and argon plasma jets: The effect comparison and the key reactive species. Physics of Plasmas, 25(2), 023508. doi:10.1063/ 1.5010724 
Authors

Zeyu Chen, Qingjie Cui, Chen Chen, Dehui Xu, Dingxin Liu, H. L. Chen, and Michael G. Kong 


\section{Inactivation of myeloma cancer cells by helium and argon plasma jets: The effect comparison and the key reactive species}

Zeyu Chen, Qingjie Cui, Chen Chen, Dehui Xu, Dingxin Liu, H. L. Chen, and Michael G. Kong

Citation: Physics of Plasmas 25, 023508 (2018); doi: 10.1063/1.5010724

View online: https://doi.org/10.1063/1.5010724

View Table of Contents: http://aip.scitation.org/toc/php/25/2

Published by the American Institute of Physics

\section{Articles you may be interested in}

Perspective: The physics, diagnostics, and applications of atmospheric pressure low temperature plasma sources used in plasma medicine

Journal of Applied Physics 122, 020901 (2017); 10.1063/1.4993710

Comparison between the water activation effects by pulsed and sinusoidal helium plasma jets

Physics of Plasmas 25, 013520 (2018); 10.1063/1.5016510

Modeling study on the effects of pulse rise rate in atmospheric pulsed discharges

Physics of Plasmas 25, 023509 (2018); 10.1063/1.5011949

High power long pulse microwave generation from a metamaterial structure with reverse symmetry

Physics of Plasmas 25, 023102 (2018); 10.1063/1.5016545

Mechanisms of fine structure formation in dielectric barrier discharges

Physics of Plasmas 25, 023502 (2018); 10.1063/1.5006345

Effects of pressure and incident field on visible light intensity from microwave nitrogen breakdown

Physics of Plasmas 25, 022104 (2018); 10.1063/1.5017872

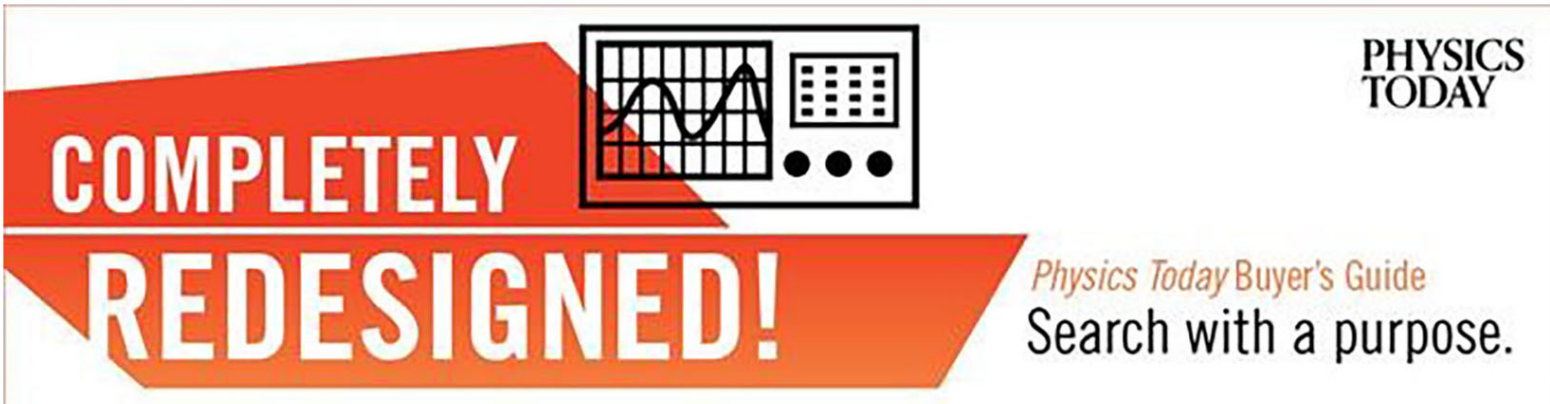




\title{
Inactivation of myeloma cancer cells by helium and argon plasma jets: The effect comparison and the key reactive species
}

\author{
Zeyu Chen, ${ }^{1}$ Qingjie Cui, ${ }^{2}$ Chen Chen, ${ }^{1}$ Dehui Xu, ${ }^{1, a)}$ Dingxin Liu, ${ }^{1, a)}$ H. L. Chen, ${ }^{3}$ \\ and Michael G. Kong 1,3,4,a) \\ ${ }^{1}$ State Key Lab of Electrical Insulation and Power Equipment, Center for Plasma Biomedicine, \\ Xi' an Jiaotong University, Xi' an, Shaanxi 710049, People's Republic of China \\ ${ }^{2}$ The school of Life Science and Technology, Xi' an Jiaotong University, Xi' an 710049, China \\ ${ }^{3}$ Frank Reidy Center for Bioelectrics, Old Dominion University, Norfolk, Virginia 23508, USA \\ ${ }^{4}$ Department of Electrical and Computer Engineering, Old Dominion University, Norfolk, Virginia 23529, USA
}

(Received 26 October 2017; accepted 22 January 2018; published online 7 February 2018)

\begin{abstract}
In plasma cancer therapy, the inactivation of cancer cells under plasma treatment is closely related to the reactive oxygen and nitrogen species (RONS) induced by plasmas. Quantitative study on the plasma-induced RONS that related to cancer cells apoptosis is critical for advancing the research of plasma cancer therapy. In this paper, the effects of several reactive species on the inactivation of LP-1 myeloma cancer cells are comparatively studied with variable working gas composition, surrounding gas composition, and discharge power. The results show that helium plasma jet has a higher cell inactivation efficiency than argon plasma jet under the same discharge power. By comparing the concentration of aqueous phase reactive species and the cell inactivation efficiency under different working gases and discharge powers, it is demonstrated that the inactivation efficiency of LP-1 myeloma cancer cells is strongly correlated with the concentration of peroxynitrite (ONOOH/ONOO ${ }^{-}$). Published by AIP Publishing. https://doi.org/10.1063/1.5010724
\end{abstract}

\section{INTRODUCTION}

In recent years, the biomedical applications of cold atmospheric plasmas (CAPs) have showed a thriving prospect. $^{1-3}$ As a strategy for cancer treatment, CAPs have received increasing attention due to their effective induction of cancer cell apoptosis and selectivity in killing cancer cells. $^{4-7}$ Among the various kinds of CAP sources, the atmosphere pressure plasma jet (APPJ) is widely used because it can directly deliver plasma onto treated tissues and cells. ${ }^{8}$ While modulating the cancer cells inactivation effect, some studies focus on the external parameters of the plasma source, such as the applied voltage, the discharge power, the waveform and frequency of the voltage, and the electrode structure. ${ }^{9-11}$ Some try to change the concentration of downstream reactive species. ${ }^{12,13}$ However, regardless of which parameters are adjusted in the upstream gas region, the effect of the application is achieved by regulating the type and concentration of reactive species in the downstream liquid region where the tissues and cells exist. The reported studies have shown that inactivation of cancer cells is a synergistic effect, ${ }^{14}$ which is closely related to the reactive oxygen species (ROS) and reactive nitrogen species (RNS) that exist in extracellular and intracellular environment of the cancer cells. ${ }^{15-17}$ The most concerned ROS include hydroxyl $(\mathrm{OH})$, hydrogen peroxide $\left(\mathrm{H}_{2} \mathrm{O}_{2}\right)$, superoxide anion $\left(\mathrm{O}_{2}{ }^{-}\right)$, etc., ${ }^{18-22}$ and RNS include nitric oxide (NO), nitric acid, nitrous acid, and peroxynitrite $\left(\mathrm{ONOOH} / \mathrm{ONOO}^{-}\right) .^{23-25}$ The current researches mainly focus on the effect of the whole population of reactive oxygen and nitrogen species (RONS) induced by plasmas $^{26}$ and rarely focus on the role of a

\footnotetext{
${ }^{a)}$ Electronic addresses: dehuixu@hotmail.com; liudingxin@mail.xjtu.edu.cn; and mglin5g@gmail.com
}

specific reactive species. That is because, on the one hand, plasma induces a variety of types of reactive species in the aqueous phase at the same time, and it is difficult to sort out the role of a specific species; on the other hand, due to the complexity of chemical reactions, it is difficult to regulate just one kind of species without change in the others. Clarifying the role of a specific reactive species will not only help to decouple the complexity of the effects of multiple reactive species but also help to selectively regulate the function of the plasma for a specific biomedical application.

In this paper, the LP-1 myeloma cancer cell is treated by helium and argon plasma jets. The RONS in aqueous phase are detected under the same treatment conditions. By changing the plasma parameters of working gas composition, discharge power and surrounding gas composition, the dependence of inactivation efficiency of LP-1 cells on the concentrations of several reactive species is investigated. The results show that under the same discharge power, He plasma jet shows a higher cell inactivation efficiency than Ar plasma jet, and the inactivation efficiency of LP-1 myeloma cancer cells is closely related to the concentration of peroxynitrite.

\section{EXPERIMENTAL SETUP}

\section{A. Plasma jet device}

Figure 1(a) shows the schematic diagram of the experimental setup. The APPJ source is fixed in a polyethylene tube by isolated upholders. The quartz tube is funnel-shaped. The tube has a wall thickness of $1 \mathrm{~mm}$. The high-voltage electrode and the ground electrode are both ring-shaped. High-voltage electrode and ground electrode closely adhere to the inside and outside of the quartz tube, respectively. The details of the dimensions are marked in the diagram. This electrode structure 
(a)

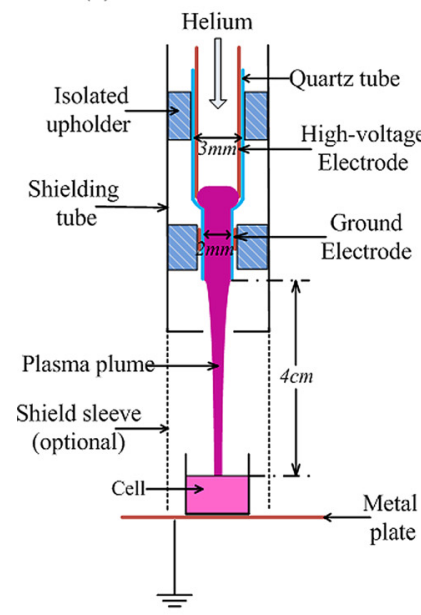

(b)

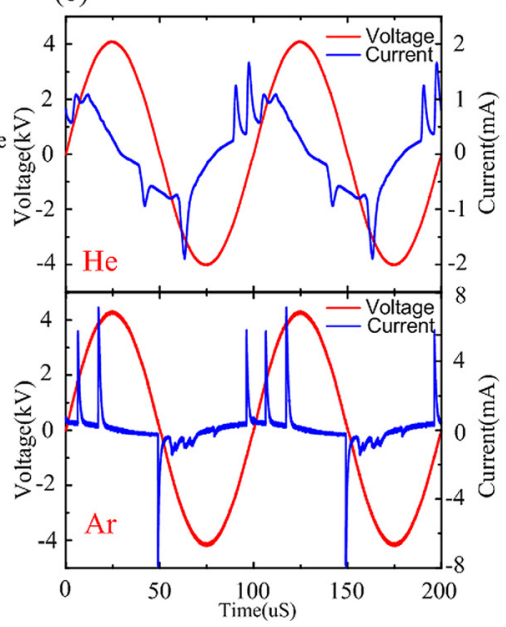

(c)

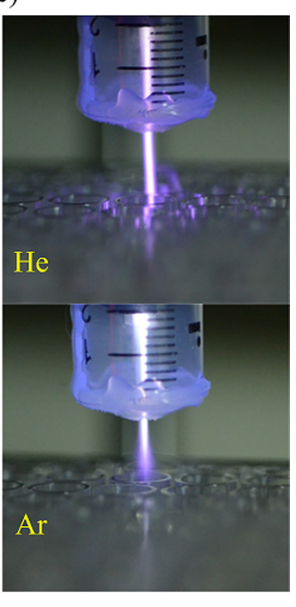

FIG. 1. (a) The schematic diagram of the experimental setup, (b) the voltage and current diagram and (c) the image of the discharge of helium and argon under the same discharge power conditions. facilitates reducing the discharge voltage and extending the length of the jet plume. The working gas is pure helium (purity $=99.99 \%$ ) or pure argon (purity $=99.99 \%$ ). A $10 \mathrm{kHz}$ sinusoidal power supply is applied on the jet device. The peakto-peak voltage of helium jet is $8 \mathrm{kV}$. Under the same discharge power, the peak-to-peak voltage of argon jet is $8.6 \mathrm{kV}$. An optional shield sleeve is utilized in some cases to isolate the ambient air around the plasma plume. Cell culture dish is placed on a grounded metal plate. The plasma jets are in direct contact with the liquid surface. Figure 1(b) shows the voltage and current waveforms of the discharge under the same discharge power. Compared to that of the argon plasma jet, the discharge current of the helium plasma jet has wider pulses but the peak values are lower. Figure 1(c) shows the images of the helium and argon plasmas with the same discharge power. In comparison, the helium plasma plume is brighter.

\section{B. Measurements on aqueous reactive species}

The phosphate buffer solution (PBS) is treated with the plasma jet to investigate the aqueous phase species for PBS can resist the changes in $\mathrm{pH}$ induced by the plasma jet like the cell culture medium. There are two reasons for the use of PBS instead of the culture medium in the diagnosis of aqueous phase species. First, some of the nutrients in the culture medium may interfere with the chemical probes used in the experiments, making it impossible to accurately measure the concentration of some reactive species in the aqueous phase. Second, under the same treatment condition, the concentrations of RONS in PBS will change proportionally from culture media to PBS. Thus, the concentration relationship of the reactive species measured in the cell culture medium can be reflected in the PBS. A $300 \mu$ l culture medium or PBS is added in one well of the cell culture dish before the plasma treatment. ROS such as $\mathrm{OH}$ and reactive nitrogen species such as peroxynitrite are short-lived species, which are measured by an electron spin resonance (ESR) spectrometer (Bruker BioSpin GmbH, EMX). ${ }^{27}$ For the measurements of peroxynitrite, a spin trapping reagent, namely, TEMPONE$\mathrm{H}$ (1-Hydroxy-2,2,6,6-tetramethyl-4-oxo-piperidine, Enzo) is added into the PBS before the plasma treatment with a concentration of $10 \mathrm{mM}$, and after plasma treatment the spin adduct of TEMPONE is measured by ESR spectrometer. It should be noted that $\mathrm{O}_{2}{ }^{-}$can also react with TEMPONE-H to produce the same adduct TEMPONE. In this regard, CYPMPO ((5-(2,2-imethyl-1,3-propoxycyclophosphoryl)-5methyl-1-pyrroline N-oxide, Cayman), a specific spin trapping reagent for $\mathrm{O}_{2}$ is also used to distinguish $\mathrm{O}_{2}{ }^{-}$and peroxynitrite. ${ }^{28}$ The usage of CYPMPO is similar to TEMPONE-H, and the spin adduct is CYPMPO-OH. Another spin trapping reagent, DMPO (5,5-dimethyl-1- pyrrolineN-oxide, Dojindo) is employed to detect $\mathrm{OH}$ in aqueous phase with a concentration of $1 \mathrm{mM}$. DMPO can react with both $\mathrm{OH}$ and $\mathrm{O}_{2}{ }^{-}$to produce DMPO-OH, but the reaction with $\mathrm{OH}$ is much faster, and hence the DMPO will bind quicker with $\mathrm{OH}$ in the presence of the same amount of $\mathrm{OH}$ and $\mathrm{O}_{2}{ }^{-29} \cdot{ }^{29}$ All the spin trapping reagents are added into the solution before the plasma treatment. After the treatment, the treated solution is loaded into a $50 \mu \mathrm{l}$ capillary quartz tube and then detected by the ESR. The center field of ESR is set to $3360 \mathrm{G}$, and the sweep width is $100 \mathrm{G}$. The g-Factor here is 2 . The receive gain is $30 \mathrm{~dB}$, and each spectrum is scanned for five times. The Amplex ${ }^{\circledR}$ Red reagent is employed to detect $\mathrm{H}_{2} \mathrm{O}_{2}$. It reacts with $\mathrm{H}_{2} \mathrm{O}_{2}$ to produce red-fluorescent oxidation product, which is excited at $\lambda=550 \mathrm{~nm}$ and the emission at $\lambda=595 \mathrm{~nm}$ and measured by a microplate reader (Thermo Scientific Varioskan ${ }^{\circledR}$ Flash Reader). Coumarin Boronic Acid (CBA) (Item No. 14051) is a fluorescent probe, which can react with peroxynitrite, $\mathrm{H}_{2} \mathrm{O}_{2}$ and $\mathrm{HClO}$ with an excitation wavelength of $332 \mathrm{~nm}$ and an emission wavelength of $420 \mathrm{~nm}$. CBA was incubated with samples at $100 \mu \mathrm{M}$ for $30 \mathrm{~min}$ and then measured by the microplate reader as well. Because the PBS and working gas used here do not contain any chlorine element, the fluorescent intensity at $420 \mathrm{~nm}$ reflects the concentrations of both $\mathrm{H}_{2} \mathrm{O}_{2}$ and peroxynitrite. The results in Sec. III D proved that the reaction efficiency of hydrogen peroxide with CBA is very slow in the reaction time of $30 \mathrm{~min}$, and the fluorescence intensity represents the concentration of peroxynitrite.

\section{Measurements of cell viability and apoptosis}

Human myeloma LP-1 cells are cultured in Roswell Park Memorial Institute (RPMI) 1640 medium supplemented with $10 \%$ fetal calf serum, $100 \mathrm{U} / \mathrm{ml}$ penicillin, $50 \mu \mathrm{g} / \mathrm{ml}$ 
streptomycin, and $2 \mathrm{mM}$ l-glutamine (all from Hyclone, Logan, UT, USA), in an atmosphere of $5 \% \mathrm{CO}_{2}$ at $37^{\circ} \mathrm{C}$.

Cell viability is assessed using the CellTiter-Glo assay (Promega, Madison, WI, USA) according to the manufacturer's instructions. Cell Titer-Glo measures luminescence to quantify the level of ATP, which is positively correlated with cell viability. Briefly, $100 \mu \mathrm{l}$ reagent is added to $100 \mu \mathrm{l}$ cells and the mixture is lysed by placing on an orbital shaker for $2 \mathrm{~min}$, followed by a $10 \mathrm{~min}$ incubation at room temperature. Luminescence is measured with the microplate reader.

The apoptosis of LP-1 cells after plasma treatment is detected by flow cytometry using an Annexin-V/PI apoptosis kit (BD). After the treatment for $24 \mathrm{~h}$, cells are harvested and washed twice with Dulbecco's PBS without calcium and magnesium (Corning). Cells are resuspended in $50 \mu \mathrm{l}$ $1 \times$ binding buffer (0.01 M Hepes/NaOH $(\mathrm{pH} 7.4), 0.14 \mathrm{M}$ $\mathrm{NaCl}, 2.5 \mathrm{mM} \mathrm{CaCl} 2)$ with $2 \mu \mathrm{l}$ annexinV-APC $(2 \mu \mathrm{g} / \mathrm{ml})$ and $2 \mu \mathrm{l} \mathrm{PI}(50 \mu \mathrm{g} / \mathrm{ml})$ and incubated at room temperature in the dark for $15 \mathrm{~min}$. An additional $400 \mu \mathrm{l} 1 \times$ binding buffer is added, and samples are analyzed by flow cytometry using a Accuri C6 (BD Biosciences).

The influence of plasma jets on the cell cycle is studied. After treated by $\mathrm{He}$ or Ar plasma jet, the cells are cultured for $24 \mathrm{~h}$. Then the cells are collected and stained with propidium iodide solution $(50 \mu \mathrm{g} / \mathrm{ml}$ propidium iodide, $100 \mu \mathrm{g} / \mathrm{ml}$ RNase A, $0.05 \%$ Triton $\mathrm{X}-100$ in $\mathrm{NaCl}$ ). Finally, the cells are incubated at $37^{\circ} \mathrm{C}$ in the dark for $30 \mathrm{~min}$. The DNA content of the treated cell is detected by a flow-cytometry, and the data is analyzed by FLOWJO software.

\section{RESULTS AND DISCUSSIONS}

\section{A. Inactivation effect comparison between helium and argon plasma jets}

Even under the same experimental condition, the impact of He and Ar plasma jets on cells, such as the total concentration of intracellular ROS, are not the same. ${ }^{30}$ Figure 2 shows the viability of LP-1 cancer cells after being treated by the helium and argon plasma jets. The cells are treated for 20, 30, and $40 \mathrm{~s}$ by helium plasma jet with a peak-to-peak voltage of $8 \mathrm{kV}$ and Ar plasma jet with a peak-to-peak voltage of $8.6 \mathrm{kV}$, respectively. Under these voltages, the discharge powers of the two jets are the same. After the treatment, the cells are cultured in $37^{\circ}$ incubator. Figures 2(a) and 2(b) show the relative cell viability after culturing for 24 and $48 \mathrm{~h}$, respectively, and the data is normalized to the control group. The cell viability is dramatically decreased both in the Ar and He plasma treatment groups. He plasma treatment shows a greater reduction of cell viability compared to Ar plasma, indicating that helium plasma jet has a stronger effect on the inactivation of cancer cells at the same discharge power.

\section{B. Comprehensive RONS in aqueous phase}

Helium plasma jet and argon plasma jet are different in their working gases, but under the same discharge power, the energy they act on cells is the same. The reason for the different cell inactivation effect is attributed to the different composition and concentration of the reactive species in the aqueous phase generated by these two types of plasma jets. Figure 3 shows the concentrations of several reactive species in aqueous phase. PBS instead of the cell culture medium is treated by helium or argon plasma jet for $40 \mathrm{~s}$. The results of the ESR spectrum show that the TEMPONE concentration in PBS treated by the He plasma jet is about twice of that for Ar plasma jet. The concentration of TEMPONE represents the concentration of two species: short-lived species $\mathrm{O}_{2}{ }^{-}$and peroxynitrite. It is vital to distinguish the origin species of TEMPONE, so another spin trap CYPMPO is used here. The ESR spectrum of CYPMPO-OH is not detected in PBS treated by both plasma jets. So the concentration of $\mathrm{O}_{2}{ }^{-}$is ignorable in this experiment. At the same time, the concentration of DMPO-OH in PBS treated with helium plasma jet is higher than that for argon plasma jet, indicating that the concentration of $\mathrm{OH}$ is higher in PBS treated by helium plasma jet. The fluorescence intensity of the microplate reader shows that the concentration of $\mathrm{H}_{2} \mathrm{O}_{2}$ in the PBS treated by Ar plasma jet is higher than that of He plasma jet. The current study concludes that the inactivation efficiency of cancer cells is closely proportional and related to the concentration of reactive species. The results of cell inactivation show that the helium plasma jet has a higher efficiency. But among the above several reactive species, the concentration of hydrogen peroxide is not consistent with the cell inactivation effect. Hydrogen peroxide is regarded as the most important species in the inactivation of cancer cells in many studies. $^{21,22,33}$ However, the inactivation efficiency is not consistent with the concentration of $\mathrm{H}_{2} \mathrm{O}_{2}$ in this paper. But this is not contrary to experiments with other plasma jets, for the inactivation of cancer cells induced by plasmas is a synergistic effect. $\mathrm{H}_{2} \mathrm{O}_{2}$ in this experiment do have contribution to the inactivation effect, but other reactive species also affect the efficiency of cancer cells inactivation. ${ }^{24}$ We think it is the concentration difference of other species that cause the diversity of the inactivation efficiency.
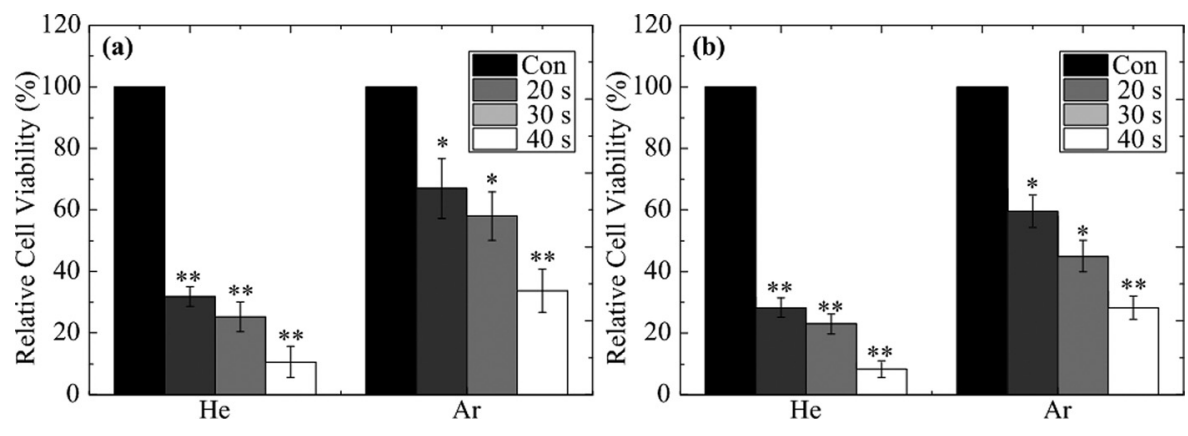

FIG. 2. The viability of LP-1 cancer cell after the treated by helium and argon plasma jets for (a) $24 \mathrm{~h}$ and (b) $48 \mathrm{~h}$. 

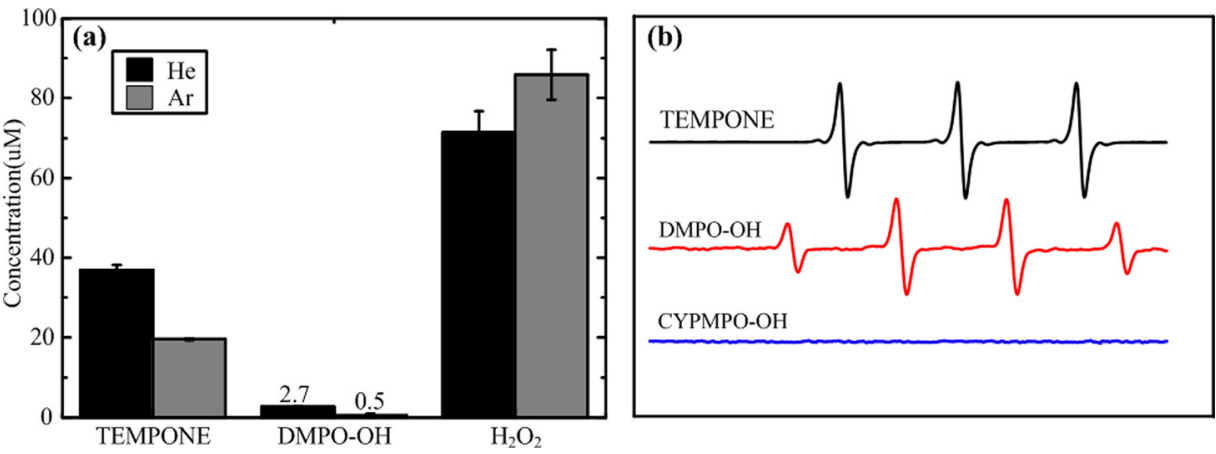

FIG. 3. (a) The concentration of several reactive species in aqueous phase. (b) ESR spectrum of TEMPONE, DMPO$\mathrm{OH}$ and CYPMPO-OH detected in this paper.
The concentration of the reactive species such as nitrate, nitrite, and ozone are detected in the experiments, but their concentrations are too low to be distinguished from the control group (untreated PBS). The $\mathrm{NO}_{2}{ }^{-}$and $\mathrm{NO}_{3}{ }^{-}$are detected by a microplate reader (Thermo Scientific Varioskan ${ }^{\circledR}$ Flash Reader) using Griess reagent and nitrate reductase enzyme. $\mathrm{O}_{3}$ is detected by a spectrophotometer (Hach, DR3900) using indigo reagent. The protocol is the same as presented in our group's previous paper. ${ }^{32}$ That is probably because the funnel-shaped quartz tube constrains the working gas flow and little air diffuses into plasma plume, so there is little those species generated.

\section{Cell inactivation effect and liquid species concentration under unequal power condition}

In order to further investigate the relationship between the concentrations of reactive species and the diversity of inactivation efficiency, the applied voltage of Ar plasma jet is adjusted to $10 \mathrm{kV}$, and the voltage of He plasma jet remains constant. The cells are treated for $40 \mathrm{~s}$ under the above conditions, and cell viability is measured after incubation for $24 \mathrm{~h}$. At the same time, aqueous reactive species are diagnosed under the two different working gases. Figure 4(a) is the cell viability after plasma treatment. When the discharge voltage of Ar plasma jet is adjusted to $10 \mathrm{kV}$, the cell viability is smaller than that of helium plasma jet of $8 \mathrm{kV}$, indicating that the inactivation effect of Ar plasma is stronger. Figure 4(b) shows the concentration of TEMPONE and DMPO-OH in aqueous phase. Concentration of DMPO-OH in PBS treated by Ar plasma jet with $10 \mathrm{kV}$ is still less than that of He plasma jet, which is not consistent with the result of cell viability, indicating $\mathrm{OH}$ is not the key factor in cancer cells inactivation. So peroxynitrite is most likely to be the key species that causes the inactivation of cancer cells, for the concentration of TEMPONE is consistent with the cell inactivation efficiency.

\section{Measurement of the key species peroxynitrite}

If peroxynitrite is a key factor in the process of cell inactivation, its concentration in the liquid phase should be consistent with the effect of cell inactivation. Here, the concentration of peroxynitrite is detected by another reagent, CBA. Figure 5(a) shows the fluorescence intensity of PBS containing $100 \mu \mathrm{M} \mathrm{CBA}$ under three treating conditions. The black bar represents Ar plasma jet with an applied voltage of $8.6 \mathrm{kV}$, the deep gray bar represents He plasma jet of $8 \mathrm{kV}$, and the light gray bar represents Ar plasma jet of $10 \mathrm{kV}$. It is found that the intensity of fluorescence is consistent with the efficiency of cell inactivation under these three conditions. Figure 5(b) is the fluorescence intensity curve of different concentration of $\mathrm{H}_{2} \mathrm{O}_{2}$ reacted with $100 \mu \mathrm{M}$ CBA solution after incubated for half an hour. The line shows that the reaction efficiency of hydrogen peroxide with $\mathrm{CBA}$ is very slow in the reaction time of $30 \mathrm{~min}$, and the fluorescence intensity of hydrogen peroxide is almost the same as that of PBS. So the fluorescence intensity represents the concentration of peroxynitrite, excluding the impact of $\mathrm{H}_{2} \mathrm{O}_{2}$. Therefore, the above deduction further suggests that the cell inactivation effect is closely related to the concentration of peroxynitrite.

\section{E. Direct evidence: Regulate peroxynitrite concentration and the cell inactivation effect}

Further experiments are made to directly correlate the effect of cell inactivation with the concentration of peroxynitrite. The peroxynitrite in aqueous phase mainly forms in the gas phase and diffuses into the aqueous phase. The reactions are given $^{31,33}$

$$
\begin{aligned}
& \mathrm{NO}_{2}+\mathrm{OH} \rightarrow \mathrm{ONOOH}, \\
& \mathrm{NO}+\mathrm{HO}_{2} \rightarrow \mathrm{ONOOH} .
\end{aligned}
$$
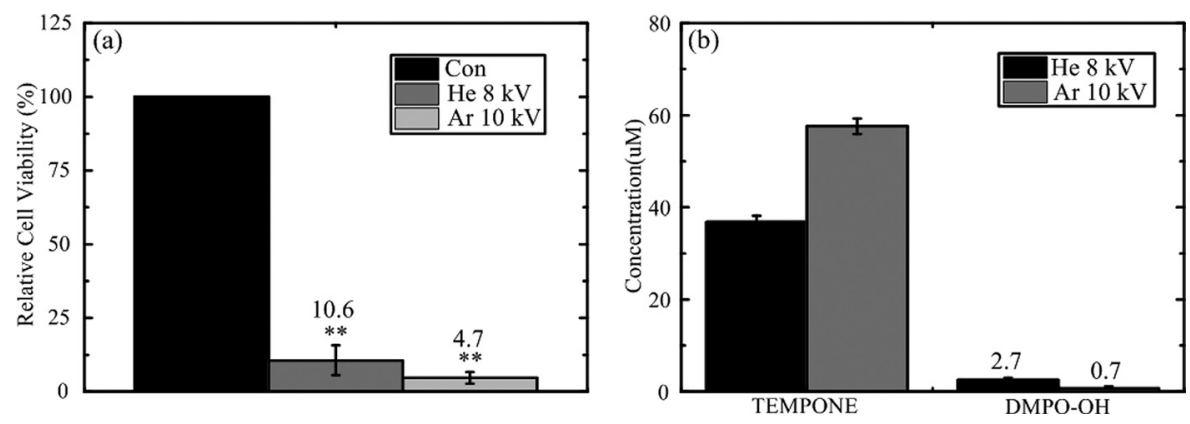

FIG. 4. (a) The cells inactivation effect of helium plasma jet in $8 \mathrm{kV}$ and argon plasma jet in $10 \mathrm{kV}$ compared to control group. (b) The concentration of TEMPONE and $\mathrm{OH}$ in aqueous phase correspondingly. 

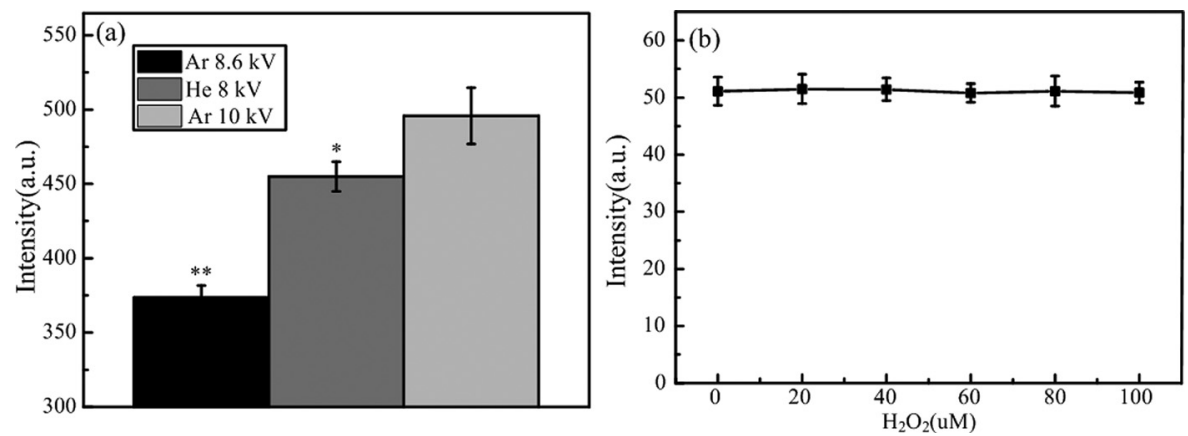

FIG. 5. (a) The fluorescence intensity of PBS containing $100 \mu \mathrm{M} \mathrm{CBA}$ under three treatment conditions. (b)The fluorescence intensity curve of different concentrations of $\mathrm{H}_{2} \mathrm{O}_{2}$ in PBS after mixed with $100 \mu \mathrm{M}$ CBA for half an hour.

In the same time, peroxynitrite can form by another reaction in the aqueous phase ${ }^{33}$

$$
\begin{gathered}
\mathrm{NO}_{2}^{-}+\mathrm{H}_{2} \mathrm{O}_{2}+\mathrm{H}^{+} \rightarrow \mathrm{O}=\mathrm{NOOH}+\mathrm{H}_{2} \mathrm{O} \\
\mathrm{O}=\mathrm{NOOH} \leftrightarrow \mathrm{ONOO}^{-}+\mathrm{H}^{+} .
\end{gathered}
$$

In either case, $\mathrm{NO}_{2}$ and $\mathrm{NO}$ formed in gas phase by the dissociation of $\mathrm{N}_{2}$ and $\mathrm{O}_{2}$ are necessary. ${ }^{32}$ If the air diffused into the plasma plume is reduced, then the reactants that generate peroxynitrite will be reduced. If the cell inactivation effect is weakened correspondingly, the key role of peroxynitrite in cell inactivation will be directly demonstrated. A shielding sleeve is employed to regulate the concentration of peroxynitrite in the aqueous phase. The shielding sleeve isolates the discharge area from the outside air, and only a small amount of nitrogen diffuses into the plasma plume. LP-1 cells and PBS that contains $100 \mu \mathrm{M}$ CBA is treated by the He plasma jet of $8 \mathrm{kV}$, with and without the shielding sleeve, respectively. Figure 6 shows the cell inactivation effect and the fluorescence intensity. It can be seen that when the shield sleeve is employed [the legend is $\mathrm{He}(\mathrm{s})$ ], the concentration of peroxynitrite in aqueous phase decreases and the cell inactivation effect is also reduced, correspondingly. The above results show that peroxynitrite as one of the reactive species produced by plasma is directly related to the inactivation effect of cancer cells.

\section{F. The mechanism of inactivation of LP-1 cancer cells: Apoptosis}

To confirm the inactivation efficiency of LP-1 cancer cells by $\mathrm{He}$ and Ar plasma, cell apoptosis is measured by

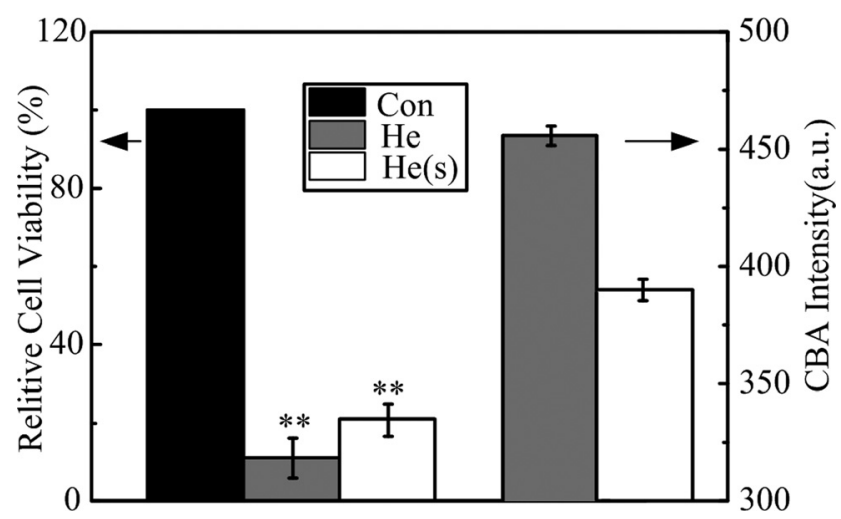

FIG. 6. The cell inactivation effect and the CBA fluorescence intensity with (legend as $\mathrm{He}$ ) and without the shield sleeve [legend as $\mathrm{He}(\mathrm{s})]$. using annexin-V/PI double staining by flow cytometry. As shown in Figure 7, the cells in the upper right area are considered as late apoptosis cells and that in the bottom right area were considered as early apoptosis cells. The percentage of early apoptosis cells has no significant difference after He and Ar plasma treatment with different applied voltage. But the percentage of later apoptosis cells was increased after different plasma treatment of $40 \mathrm{~s}$. Ar plasma jet at $8.6 \mathrm{kV}$ resulted in $25.7 \%$ of later apoptosis cells, while increasing the power supply to $10 \mathrm{kV}$ could significantly enhance the later apoptosis cells to a percentage of $51.7 \%$. He plasma jet at $8 \mathrm{kV}$, which is at the same power supply of Ar plasma jet at $8.6 \mathrm{kV}$, showed a moderate induction of cell apoptosis $(32.8 \%$ of later apoptosis cells).As for the mechanism of apoptosis of cancer cells induced by peroxynitrite, the current study suggests that peroxynitrite will cause DNA damage and weaken the antioxidant system. ${ }^{34-36}$ In the meantime, the influence of plasma jets on the cell cycle is studied. Figure 7(b) shows the cell DNA content of each phase after being treated by $\mathrm{He}$ or $\mathrm{Ar}$ plasma jet for $40 \mathrm{~s}$. As shown in the figure, more cells accumulate in G1 phase after the treatment of the plasma jets.

\section{CONCLUSION}

In order to find the key reactive species in cancer cell inactivation induced by plasma, LP-1 cancer cells are treated by helium and argon plasma jets for comparative study in this paper. The results show that helium plasma jet has higher cell inactivation efficiency than argon plasma jet under the same discharge power. The main reactive oxygen and nitrogen species (RONS) measured in the plasma-activated medium are $\mathrm{H}_{2} \mathrm{O}_{2}, \mathrm{OH}$ and peroxynitrite $\left(\mathrm{ONOOH} / \mathrm{ONOO}^{-}\right)$. The concentrations of aqueous $\mathrm{OH}$ and peroxynitrite induced by $\mathrm{He}$ plasma jet are higher than that for Ar counterpart, implying that these two species might be largely responsible for the cell inactivation. When the discharge voltage for Ar plasma jet is increased from $8.6 \mathrm{kV}$ to $10 \mathrm{kV}$, the cell activation efficiency changes to be higher, and in this case, the concentration of aqueous $\mathrm{OH}$ is still larger, but the concentration of peroxynitrite changes to be lower. These results demonstrate that it is peroxynitrite that is closely related to the cell inactivation. Direct evidence is given by regulating the concentration of peroxynitrite with a shielding tube to reduce the inclusion of surrounding air, especially $\mathrm{N}_{2}$, in the plasma region, and as a result, the concentration of aqueous peroxynitrite is greatly reduced. In that case, the cell inactivation efficiency is dramatically weakened. Although there may be other reactive 
(a)

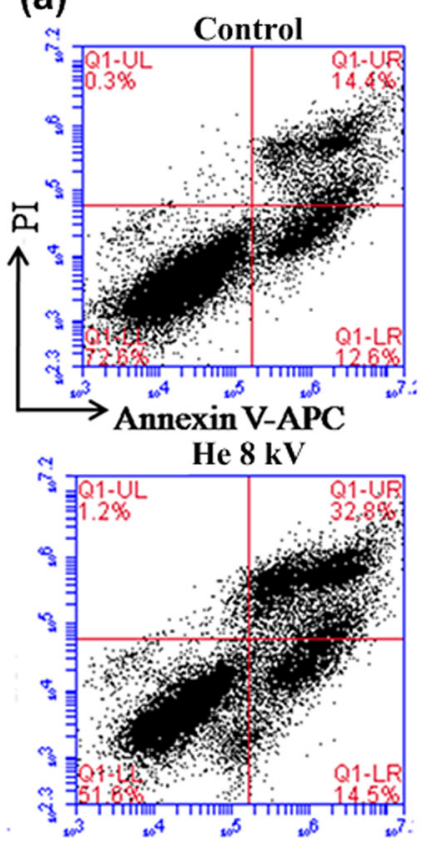

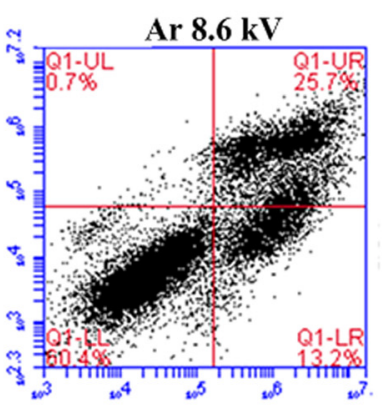

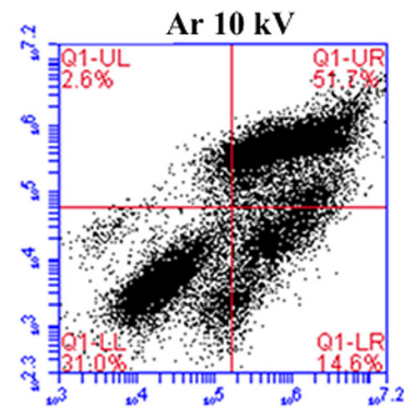

(b)

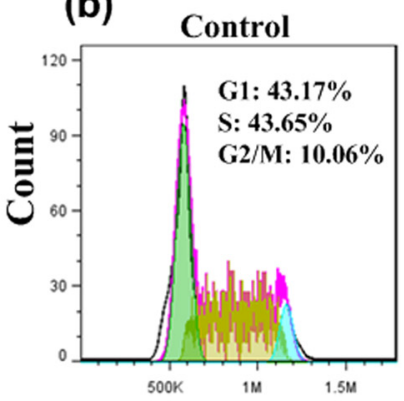

He 8 kV

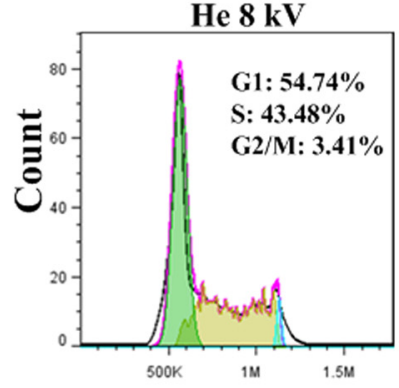

Ar 8.6 kV

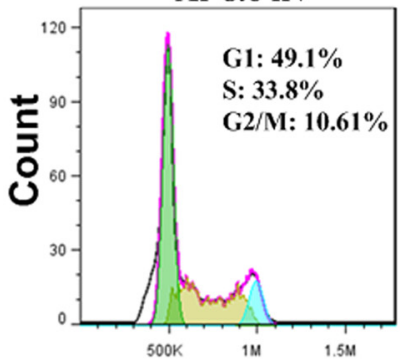

Ar 10 kV

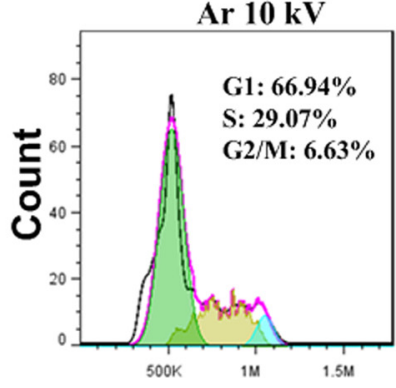

FIG. 7. (a) Analysis of cell apoptosis by flow cytometry after He and Ar plasma treatment with different applied voltage. (b) Study of cell cycle.

species that may also contribute to the inactivation of cancer cells, the results in this paper provide a research clue that the inactivation efficiency of LP-1 myeloma cancer cells is strongly correlated with the concentration of peroxynitrite $\left(\mathrm{ONOOH} / \mathrm{ONOO}^{-}\right)$.

\section{ACKNOWLEDGMENTS}

This work was supported by the National Natural Science Foundation of China (Grant Nos. 51722705 and 51521065).

${ }^{1}$ Z. Machala, B. Tarabova, K. Hensel, E. Spetlikova, L. Sikurova, and P. Lukes, Plasma Process. Polym. 10, 649-659 (2013).

${ }^{2}$ J. Shen, C. Cheng, S. Fang, H. B. Xie, Y. Lan, G. H. Ni, Y. D. Meng, J. R. Luo, and X. K. Wang, Appl. Phys. Express 5, 036201 (2012).

${ }^{3}$ C. H. Park, J. S. Lee, J. H. Kim, D. K. Kim, O. J. Lee, H. W. Ju, B. M. Moon, J. H. Cho, M. H. Kim, P. P. Sun, S. J. Park, and J. G. Eden, J. Phys. D: Appl. Phys. 47, 435402 (2014).

${ }^{4}$ S. J. Kim, H. M. Joh, and T. H. Chung, Appl. Phys. Lett. 103, 153705 (2013).

${ }^{5}$ M. Keidar, A. Shashurin, O. Volotskova, M. A. Stepp, P. Srinivasan, A. Sandler, and K. Trink, Phys. Plasmas 20, 057101 (2013).

${ }^{6}$ H. M. Joh, S. J. Kim, T. H. Chung, and S. H. Leem, Appl. Phys. Lett. 101, 053703 (2012).

${ }^{7}$ N. Georgescu and A. R. Lupu, IEEE Trans. Plasma Sci. 38(8), 1949-1955 (2010).

${ }^{8}$ X. P. Lu, Z. H. Jiang, Q. Xiong, Z. Y. Tang, and Y. Pan, Appl. Phys. Lett. 92, 151504 (2008).

${ }^{9}$ S. Kalghatgi, G. Friedman, A. Fridman, and A. M. Clyne, Ann. Biomed. Eng. 38, 748 (2010).

${ }^{10}$ S. Schneider, F. Jarzina, J. W. Lackmann, J. Golda, V. Layes, V. S. Gathen, J. E. Bandow, and J. Benedikt, J. Phys. D: Appl. Phys. 48, 444001 (2015).

${ }^{11}$ J. Park, M. Kim, M. Shiratani, A. E. Cho, E. H. Choi, and P. Attri, Sci. Rep. 6, 35883 (2016).

${ }^{12}$ D. Boehm, C. Heslin, P. J. Cullen, and P. Bourke, Sci. Rep. 6, 21464 (2016).

${ }^{13}$ C. A. J. V. Gils, S. Hofmann, B. K. H. L. Boekema, R. Brandenburgand, and P. J. Bruggeman, J. Phys. D: Appl. Phys. 46, 175203 (2013).

${ }^{14}$ X. P. Lu, G. Naidis, M. Laroussi, S. Reuter, D. Graves, and K. Ostrikov, Phys. Rep. 630, 1-84 (2016).
${ }^{15}$ T. V. Woedtke, H. R. Metelmann, and K. D. Weltmann, Contrib. Plasma Phys. 54(2), 104-117 (2014).

${ }^{16}$ X. Yan, Z. L. Xiong, F. Zou, S. S. Zhao, X. P. Lu, G. X. Yang, G. Y. He, and K. Ostrikov, Plasma Process. Polym. 9, 59-66 (2012).

${ }^{17}$ D. B. Graves, J. Phys. D: Appl. Phys. 45, 263001 (2012).

${ }^{18}$ C. Nathanand and A. H. Ding, Cell 140, 871-882 (2010).

${ }^{19}$ D. H. Xu, D. X. Liu, B. Q. Wang, C. Chen, Z. Y. Chen, D. Li, Y. J. Yang, H. L. Chen, and M. G. Kong, PLoS One 10(6), e0128205 (2015).

${ }^{20}$ D. H. Xu, B. Q. Wang, Y. J. Xu, Z. Y. Chen, Q. J. Cui, Y. J. Yang, H. L. Chen, and M. G. Kong, Sci. Rep. 6, 27872 (2016).

${ }^{21}$ K. Wende, P. Williams, J. Dalluge, W. V. Gaens, H. Aboubakr, J. Bischof, T. Woedtke, S. M. Goyal, K. D. Weltmann, A. Bogaerts, K. Masur, and P. J. Bruggeman, Biointerphases 10, 029518 (2015).

${ }^{22}$ S. Bekeschus, J. Kolata, C. Winterbourn, A. Kramer, A. Turner, K. D. Weltmann, B. Broker, and K. Masur, Free Radical Res. 48, 542-549 (2014).

${ }^{23}$ K. Bedard and K. H. Krause, Physiol. Rev. 87, 245-313 (2007).

${ }^{24}$ Z. J. Liu, D. H. Xu, D. X. Liu, Q. J. Cui, H. F. Cai, Q. S. Li, H. L. Chen, and M. G. Kong, J. Phys. D: Appl. Phys. 50, 195204 (2017).

${ }^{25}$ C. V. Sonntag, Water Sci. Technol. 58, 1015-1021 (2008).

${ }^{26}$ H. M. Joh, J. Y. Choi, S. J. Kim, T. H. Chung, and T. H. Kang, Sci. Rep. 4, 6638 (2014)

${ }^{27}$ S. A. Norberg, W. Tian, E. Johnsen, and M. J. Kushner, J. Phys. D: Appl. Phys. 47, 475203 (2014).

${ }^{28}$ A. Nakajima, Y. Sakurai, E. Matsuda, Y. Masuda, Y. Naganobu, Tajima, H. Sameshima, and T. Ikenoue, Biosci. Biotechnol. Biochem. 77(2), 324-331 (2013).

${ }^{29}$ H. Tresp, M. U. Hammer, J. Winter, K.-D. Weltmann, and S Reuter, J. Phys. D: Appl. Phys. 46, 435401 (2013).

${ }^{30}$ H. M. Joh, S. J. Kim, T. H. Chung, and S. H. Leem, AIP Adv. 3, 092128 (2013).

${ }^{31}$ G. Sara, L. Johan, and M. Gabor, Chem. Rev. 105, 2457-2470 (2005).

${ }^{32}$ T. T. He, D. X. Liu, X. Han, Z. C. Liu, D. H. Xu, D. Li, Q. S. Li, M. Z. Rong, and M. G. Kong, J. Phys. D: Appl. Phys. 49, 205204 (2016).

${ }^{33}$ P. Lukes, E. Dolezalova, I. Sisrova, and M. Clupek, Plasma Sources Sci. Technol. 23, 015019 (2014).

${ }^{34}$ D. Y. Yan, A. Talbot, N. Nourmohammadi, X. Q. Cheng, J. Canady, J. Sherman, and M. Keidar, Sci. Rep. 5, 18339 (2015).

${ }^{35} \mathrm{~F}$. Yamakura, H. Taka, T. Fujimura, and K. Murayama, J. Biol. Chem. 273, 14085-14089 (1998).

${ }^{36}$ N. B. Surmeli, N. K. Litterman, A. F. Miller, and J. T. Groves, J. Am. Chem. Soc. 132, 17174-17185 (2010). 